\title{
Penentuan Kemiripan Manfaat Tananaman Obat dengan Gejala Sakit Menggunakan Algoritma Winnowing
}

\author{
*Muryanto ${ }^{1)}$, Dony Setyawan ${ }^{2}$ \\ ${ }^{1,2)}$ Program Studi Teknik Informatika, Fakultas Ilmu Komputer, Universitas Widya Dharma Klaten, Jawa Tengah, Indonesia \\ e-mail: $\underline{\text { mury192000@ gmail.com }}^{1)}$, donnisoft@ gmail.com $^{2}$
}

\begin{abstract}
Abstrak-Pemilihan tanaman obat untuk pengobatan di masyarakat, secara umum dilakukan dengan cara membandingkan manfaat dari tanaman-tanaman tersebut dengan gejala-gejala sakit kemudian diantara tanaman yang paling mirip dengan gejala sakit itulah yang akan dipilih untuk pengobatan. Pada penelitian ini penentuan kemiripan teks gejala sakit dan teks manfaat tanaman obat akan ditentukan dengan dukungan Algoritma Winnowing. Pada Algoritma Winnowing, data teks direpresentasikan dalam bentuk fingerprint. Pada prinsipnya Algoritma Winnowing menggunakan over lapping dari k-gram, untuk mendapatkan nilai hash dari dokumen teks, kemudian menggunakan pergeseran window untuk memilih nilai hash minimum dari setiap window sehiingga mendapatkan fingerprint dari dokumen tersebut. Pada penelitian ini untuk menentukan tingkat kemiripan antara teks gejala sakit dan teks manfaat tanaman obat, maka digunakan rumusan Jaccard Coefficient, dimana jumlah fingerprint yang sama kedua dokumen akan dibagi dengan jumlah total fingerprint dari kedua dokumen tersebut.Dari hasil pengujian terhadap sistem yang dibangun, maka pengunaan parameter fingerprint berupa nilai basis $=21$ nilai gram $=7$ dan nilai window=1 menghasilkan kinerja yang cukup baik dalam penentuan kemiripan teks, hal ini ditunjukkan dengan nilai rata-rata recall sebesar $81 \%$, dan rata-rata precision sebesar $81 \%$.
\end{abstract}

Kata-kata Kunci : tanaman obat, winnowing, fingerprint, kemiripan, Jaccard Coefficient

\section{Pendahuluan}

\section{Latar Belakang}

Tanaman obat menjadi salah satu pilihan ketika ingin berobat dengan menggunakan jenis pengobatan tradisonal. Hernani dan Tri Marwati [1] menyatakan bahwa menurut Departemen Kesehatan, yang dimaksud dengan obat tradisional ialah obat yang berasal dari bahan tumbuh-tumbuhan, hewan, mineral atau sediaan galeniknya atau campuran dari bahanbahan tersebut yang belum mempunyai data klinis dan dipergunakan dalam usaha pengobatan hanya berdasarkan pengalaman. Bahan yang digunakan bisa dalam keadaan segar ataupun dalam bentuk kering yang disebut simplisia, dapat berupa rimpang, akar, herba, daun, batang, bunga dan buah. Secara umum yang dinamakan simplisia adalah bahan alamiah yang dipergunakan sebagai obat yang belum mengalami pengolahan apapun kecuali dinyatakan lain, berupa bahan yang telah dikeringkan.

Kebiasaan yang terjadi di masyarakat pada umumnya dalam memilih tanaman obat, biasanya didasarkan pada informasi manfaat tanaman tersebut. Menurut Katno [2], pakar Farmakologi juga telah banyak melakukan pembuktiaan khasiat empiris tumbuhan secara ilmiah, bahkan diantaranya telah melalui uji klinis. Informasi tanaman obat juga disediakan melalui halaman web site Badan Pengawasan Obat dan Makanan Republik Indonesia atau disingkat BPOM.

Secara sederhana pemilihan tanaman obat untuk pengobatan bisa dilakukan dengan cara melihat informasi manfaat dari tanaman-tanaman tersebut, kemudian dicocokkan dengan informasi gejala-gejala sakit kemudian yang paling mendekati dengan gejala tersebut maka tanaman itulah yang akan dipilih untuk pengobatan.

Hal ini ditunjukkan dengan melihat macammacam manfaat dari obat tersebut, misal ketika batuk dan pilek maka yang diperlukan adalah obat yang memiliki manfaat batuk dan pilek, sehingga jika ada dua obat yang memiliki manfaat pengobatan batuk dan pilek saja dan obat lain memiliki manfaat pengobatan batuk, pilek dan rematik, maka yang dipilih tentu saja yang memiliki kemiripan lebih besar, yakni obat yang pertama, karena obat yang kedua walaupun sama-sama mengandung manfaat pengobatan batuk dan pilek, namum juga kemungkinan memiliki zat yang terkait pengobatan rematik, yang tidak diperlukan saat itu karena tubuh tidak menderita sakit rematik.

Deteksi kemiripan dokumen teks sebagai bagian dari text mining merupakan upaya untuk mencari tingkat kemiripan dari dua dokumen teks yang dibandingkan. Secara umum implementasi dari prinsip tersebut pada penelitian ini adalah membandingkan data teks yang berupa keluhan-keluhan sakit, dengan data teks dari manfaat macam-macam tanaman obat, kemudian yang paling mirip maka akan dijadikan pilihan utama untuk menentukan tanaman obat yang akan dipakai. Pada kasus ini Algoritma Winnowing menjadi salah satu pilihan metode untuk mendukung penentuan kemiripan dokumen teks, untuk memilih tanaman obat untuk pengobatan.

\section{Rumusan Masalah}

Dari latar belakang yang telah dijelaskan sebelumnya, maka rumusan masalah dalam penelitian ini adalah bagaimana membangun sistem yang akan digunakan untuk mendukung pencarian dokumen teks tanaman obat berdasarkan prinsip kemiripan antara 
gejala sakit dan manfaat tanaman tanaman obat tersebut, menggunakan Algoritma Winnowing, dimana representasi data teksnya berupa fingerprint.

\section{Tinjauan Pustaka}

Sebelumnya telah ada beberapa penelitian yang telah dilakukan yang terkait dengan prinsip kemiripan dokumen teks, baik yang menggunakan algoritma Winnowing ataupun selainnya. Beberapa penelitian deteksi kemiripan dokumen telah dilakukan dengan berbagai algoritma dengan diman representasi datanya dalam beberapa formasi diantaranya dengan fingerprinting, representasi berupa kata atau term.

Purwitasari dkk.[3], telah melakukan penelitian dengan menggunakan algoritma Winnowing. Pada penelitian tersebut data teks dokumen laporan tugas mahasiswa direpresentasikan menjadi fingerprint. Penelitian tersebut bertujuan untuk mendeteksi keberadaan kalimat yang sama. Kesimpulannya dari penelitian tersebut adalah, konfigurasi nilai parameter khususnya saat pembentukan fingerprint yang kurang tepat, bisa menyebabkan deteksi keberadaan kalimat yang sama sulit ditemukan.

Penelitian lain yang juga melibatkan fingerprint juga dilakukan, oleh Salmuasih dan Sunyoto [4]. Tujuan peneltian hampir sama dengan penelitian sebelumnya yakni pendekteksian plagiarisme, namun pada penelitian ini menggunakan algoritma Rabin Karp. Pada peneltian ini disimpulkan bahwa banyaknya konten akan memperlama proses, sedangkan ukuran k gram yang kecil akan menghasilkan akurasi similaritas yang lebih baik.

Penelitian untuk mengetahui kinerja pemakaian algoritma Winnowing juga dilakukan. Kurniawati dan Wicaksana [5] melakukan penelitian untuk membandingkan kelebihan dan kekurangan antara algoritma Winnowing dan Manber dalam mendeteksi plagiarism dokumen Bahasa Inggris. Hasil penelitian ini menyimpulkan bahwa jumlah langkah pendekatan Menber lebih sedikit disbanding Winnowing, namun belum memberikan jaminan kecocokan antar dokumen. Sedangkan pendekatan Winnowing lebih baik karena selain lebih menjamin kecocokan dokumen yang dibandingkan, output yang dihasilkan juga lebih informatif karena menyertakan informasi posisi.

Aljohani dkk.[6] melakukan peneltian untuk menerapakan algoritma Winnowing dalam mendeteksi plagiarisme dokumen teks lintas bahasa Arab-Inggris, pada artikel-artikel Wikipedia. Dari hasil peneltian tersebut dinyatakan bahwa algoritma Winnowing bisa digunakan efektif untuk mendeteksi plagiarisme lintas bahasa Arab-Inggris dengan nilai $97 \%$ pada precision.

\section{Landasan Teori \\ Kemiripan Dokumen}

Pada dasarnya deteksi kemiripan dokumen teks prinsipnya sama dengan deteksi penjiplakan. Stein dan
Mayer $\mathrm{Zu}$ [7] berpendapat bahwa metode pendeteksi kemiripan dokumen teks dibagi menjadi tiga bagian yaitu metode perbandingan teks lengkap, metode dokumen fingerprinting, dan metode kesamaan kata kunci. Terdapat beberapa algoritma dalam metode dokumen fingerprinting, diantaranya: algoritma Manber, Rabin Karp, dan Winnowing.

Penelitian pertama yang menerapkan metode dokumen fingerprinting pada koleksi dokumen yaitu algoritma Rabin Karp. Algoritma Rabin Karp membandingkan seluruh pasang k-gram dalam dokumen. Algoritma tersebut relatif lebih lama dibandingkan dengan algoritma Manber dan Winnowing.

Udi Manber [8], selanjutnya menerapkan Karp-Rabin string matching untuk mendeteksi kesamaan filepada file system dengan mendapatkan fingerprint dari setiap nilai hash. Metode tersebut menciptakan gap yang terlalu jauh antara fingerprint satu dengan yang lainnya dan kecocokan di dalam gap tidak dapat terdeteksi. Sedangkan pada algoritma Winnowing akan mengambil nilai k-gram terkecil sebagai fingerprint dokumen. Dengan mengambil nilai terkecil maka akan mengurangi gap antar fingerprint, dan jumlah fingerprint yang dihasilkan akan sesuai dengan besar dokumen yang bersangkutan.

\section{Algoritma Winnowing}

Zou dkk. [9] menyatakan bahwa algoritma Winnowing menggunakan prinsip over lapping dari kgram, untuk mendapatkan nilai hash dari dokumen, kemudian menggunakan pergeseran window untuk memilih nilai hash minimum dari setiap window untuk mendapatkan fingerprint dari dokumen, dan kemudian menghitung tingkat fingerprint yang cocok untuk mendapatkan tingkat kemiripan antara dua dokumen.

Pada algoritma Winnowing melibatkan teknik hashing, pada pembuatan fingerprintnya. Pada proses hashing dokumen terlebih dahulu dibentuk dalam bagian-bagian substring dengan dengan istilah gram. Pernyataan k-gram, menyatakan panjang substring $\mathrm{k}$ dimana $\mathrm{k}$ merupakan nilai yang dipilih oleh pengguna. Dokumen akan dibagi kedalam k-gram yang mungkin, dan kemudian k-gram tersebut akan dilakukankan proses hashing.

Untuk membuat fingerprint dari hasil proses hashing, maka dilakukan pembagian dengan menggunakan window $\mathrm{w}$, dan dipilih nilai yang paling kecil. Sebagaimana yang dikemukakan Schleimer dkk.[10], dari nilai-nilai hash yang ada pada setiap window kemudian akan dipilih nilai terkecil. Jika terdapat lebih dari satu nilai terkecil yang sama pada window yang berurutan, maka dipilih hash yang berada pada posisi paling kanan di window.

Secara umum tahapan-tahapan dalam algoritma Winnowing adalah sebagai berikut

1. Menghilangkan karakter-karakter yang tidak relevan yang ada pada dokumen, misal tanda baca, dan simbol-simbol lain, termasuk spasi. 
2. Membentuk rangkaian k-gram dari dokumen teks, dengan $\mathrm{k}$ adalah jumlah karakter dalam setiap gram

3. Melakukan hashing untuk setiap gram dengan melibatkan tiap karakter pada gram. Adapun rumusan fungsi hash dari Richard M. Karp dan Michael O. Rabin [11]:

$$
\begin{gathered}
\operatorname{Hash}_{\left(c_{1} \ldots c_{k}\right)}=c_{1} * b^{(k-1)}+c_{2} * b^{(k-2)}+ \\
\cdots+c_{(k-1)} * b+c_{k}
\end{gathered}
$$

Dimana :

$\mathrm{c}_{\mathrm{i}}$ adalah nilai ASCII karakter ke $\mathrm{i}$

$\mathrm{b}$ adalah basis yang berupa bilangan bulat

$\mathrm{k}$ adalah ukuran gram

4. Membentuk window-window berdasar dari nilainilai hash dari proses sebelumnya. Tiap window merupakan kumpulan hash dari gram. Nilai window ditunjukkan dengan variable w. misal $\mathrm{w}=4$ maka setiap window terdiri dari 4 nilai hash dari 4 gram tersebut.

5. Menentukan fingerprint dari setiap window, yakni mengambil sebuah nilai terkecil dari setiap window.

Adapun contoh penggambaran algoritma Winnowing seperti yang dikemukakan Schleimer dkk. [10] adalah sebagai berikut :

Contoh sebuah teks : a do run run run, a do run run

1. Hilangkan karakter-karakter tidak diperlukan, termasuk spasi adorunrunrunadorunrun

2. Bagi menjadi potongan berlipat yang disebut gram, misal gram ukuran 5, maka akan didapat:

adoru dorun orunr runru unrun nrunr runru unrun nruna runad unado nador adoru dorun orunr runru unrun

3. Rubah gram menjadi nilai hash, misal sebagai berikut

$777442 \quad 1798501798 \quad 8 \quad 88673977 \quad 74$
421798

4. Membentuk window dari nilai hash, misal window berukuran 4

$(77,74,42,17)(74,42,17,98)$

$(42,17,98,50)(17,98,50,17)$

$(98,50,17,98)(50,17,98,8)$

$(17,98,8,88)(98,8,88,67)$

$(8,88,67,39)(88,67,39,77)$

$(67,39,77,74)(39,77,74,42)$

$(77,74,42,17)(74,42,17,98)$

5. Memilih hash-hash pada window sebagai fingerprint-fingerprint

171783917

6. Fingerprint dan posisinya, dimulai dari posisi 0 $[17,3][17,6][8,8][39,11][17,15]$

\section{a. Jaccard's SimilarityCoefficient}

Pengukuran tingkat kemiripan teks pada penelitian ini menggunakan rumusan Jaccard's similarity coefficient. Adapun implementasi rumusan tersebut untuk penghitungan kemiripan teks yang menggunakan fingerprint sebagai representasi teksnya adalah jumlah fingerprint yang sama antar kedua file teks yang dibandingkan dibagi dengan jumlah total fingerprint dari kedua teks. Adapun rumusan Jaccard's Similarity Coefficient adalah sebagai berikut [12]:

$D(A, B)=\frac{|A \cap B|}{|A \cup B|} \times 100$

Dimana :

$\mathrm{D}(\mathrm{A}, \mathrm{B})$ adalah nilai kemiripan dokumen A terhadap B

$|\mathrm{A} \cap \mathrm{B}|$ adalah banyaknya fingerprint yang sama antara dokumen A dan B

|AUB $\mid$ adalah jumlah fingerprint dari dokumen A dan $\mathrm{B}$

\section{Precision dan Recall}

Untuk mengetahui sejauh mana kinerja system yang dibangun, maka dilakukan pengukuran kinerja sistem. Adapun parameter yang digunakan dalam pengukuran ini adalah menggunakan precision dan recall. Sebagaimana dinyatakan oleh Guojun lu [13], recall dan precision secara kolektif digunakan untuk mengukur sejauh mana efektifitas dari sebuah information retrieval system atau sistem pencarian informasi.

Pada saat proses pencarian informasi pada sebuah sistem tersebut, maka recall menunjukkan perbandingan antara jumlah item yang relevan yang terambil dibanding dengan jumlah item relevan yang terdapat dalam basis data, sedangkan precision menunjukan perbandingan antara item yang relevan yang terambil dengan jumlah keseluruhan item yang terambil.

Hubungan relevansi hasil query dengan keterambilan dokumen dapat digambarkan seperti tabel berikut ini.

\begin{tabular}{|c|c|c|}
\hline Dokumen & Relevan & Tidak Relevan \\
\hline Terambil & $\begin{array}{l}\text { True Positives } \\
\text { (tp) }\end{array}$ & False Positives(fp) \\
\hline $\begin{array}{l}\text { Tidak } \\
\text { terambil }\end{array}$ & $\begin{array}{l}\text { False } \\
\text { Negatives }(f n)\end{array}$ & True Negatives(tn) \\
\hline
\end{tabular}

Tabel 1. Relevansi keterambilan dokumen dengan query

Dari keterangan sebelumnya dan gambaran tabel tersebut maka precison dan recall juga dapat dirumuskan sebagai berikut [14]

Precision $=\frac{t p}{t p+f p}$

Recall $=\frac{t p}{t p+f n}$

\section{Metode}

Bahan Penelitian

Bahan penelitian ini berasal dari dokumen halaman-halaman web site yang berisi informasi 
tanaman obat yang bersumber dari BPOM Republik Indonesia di situs http://www.pom.go.id. Adapun contoh tampilan halaman web site tersebut seperti gambar 1 berikut ini.

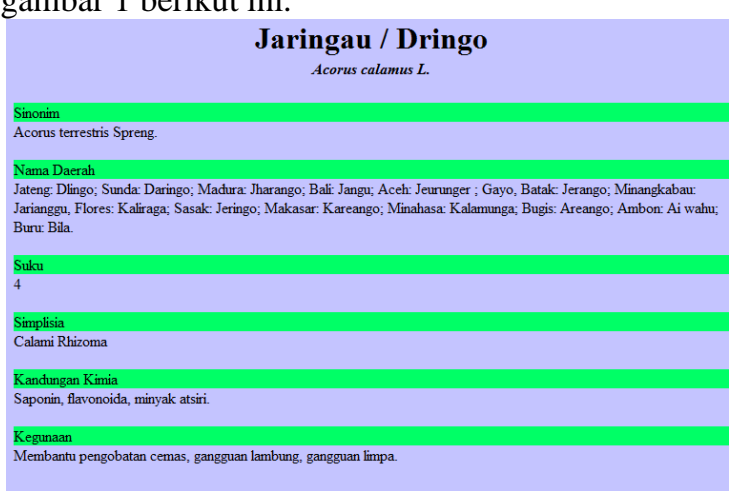

Gambar 1. Contoh halaman web site tanaman obat Dringo

Proses selanjutnya dari kumpulan halamanhalaman web site tersebut kemudian diekstraks menjadi file-file teks dan kemudian disimpan pada folder lokal, seperti gambar 2 berikut ini.

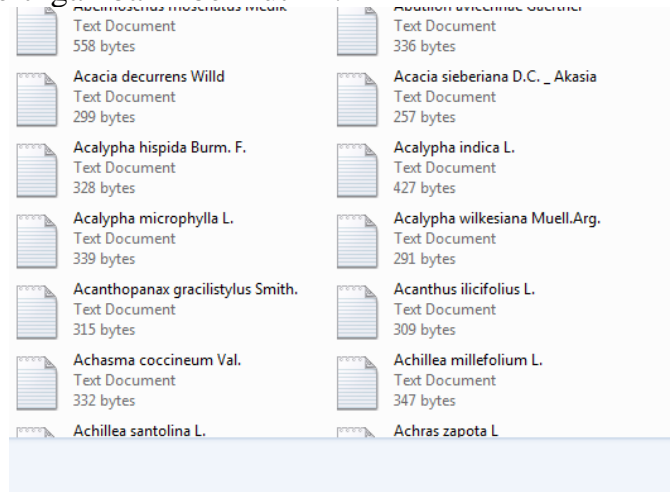

Gambar 2. Folder kumpulan file teks tanaman obat

Pada setiap file teks tersebut berisi informasi tanaman obat, yang sesuai dengan tampilan di halaman web site yang menjadi sumbernya.

\section{Alat penelitian}

Berdasarkan konsep-konsep yang telah dijelaskan sebelumnya, selanjutnya dibangun sistem yang berupa perangkat lunak dengan menggunakan kode program, menggunakan bahasa pemrograman Java dengan memakai software NetBeans IDE 8.2, dan juga DBMS MySQL Server 5.1.

\section{Gambaran sistem yang dibangun}

Dalam sistem ini data teks, baik tanaman obat, dan gejala sakit yang dimasukkan ke sistem, akan mengalami preprocessing. Untuk tanaman obat bagian yang diperlukan adalah bagian manfaat tanaman obat. Tahapan tersebut adalah :
a. Pembersihan karakter tidak relevan
b. Filtering
c. Casefolding

Data teks manfaat tanaman obat inilah yang nantinya akan dihitung nilai kemiripannya dengan data teks gejala sakit atau keluhan yang diinputkan user.

Tahapan pertama preprocessing yang dilakukan adalah pembersihan koleksi data teks dari karakter-karakter yang mengganggu atau tidak relevan seperti ", ', +, -, /, *, !, @, ।, \#, \$, \%, ^, \&, (, ), \{, \}, |, <, $\left.>, \sim,:, ;,=, !, ?,{ }_{-},\right], \backslash,[$, .

Proses selanjutnya adalah filtering yakni membersihkan data teks dari kata-kata yang tidak tidak relevan atau sering diistilahkan dengan stopword, misal kata 'dan','atau', 'yang', dan lainnya. Pada tahapan terakhir preprocessing adalah casefolding, yakni menyeragamkan huruf-huruf yang ada pada teks menjadi huruf kecil semua.

Sebagai contoh file teks Acorus calamus L.txt, memiliki teks manfaat 'membantu pengobatan cemas, ganguan lambung, gangguan limpa'. Setelah teks tersebut dilakukan preprocessing maka akan menjadi:'membantupengobatancemasgangguanlambun ggangguanlimpa'.

Tahapan selanjutnya setelah preprocessing adalah proses fingerprinting dengan menggunakan prinsip Algoritma Winnowing. Tahapan ini terdiri dari proses

\section{Pembentukan gram \\ 2. Hashing \\ 3. Fingerprinting}

Pada penelitian ini pembentukan gram adalah berbasis karakter. Sebagai contoh dari data di atas, maka dengan ukuran gram 6 akan dihasilkan deretan gram :
[memban][embant][mbantu][bantup][antupe]
[ntupen][tupeng][upengo][pengob][engoba]
[ngobat][gobata][obatan][batanc][atance]
[tancem][ancema][ncemas][cemasg][emasga]
[masgan][asgang][sgangg][ganggu][anggua]
[ngguan][gguanl][guanla][uanlam][anlamb]
[nlambu][lambun][ambung][mbungg][bungga]
[unggan][nggang][ggangg][ganggu][anggua]
[ngguan][gguanl][guanli][uanlim][anlimp]
[nlimpa].

Proses selanjutnya adalah hashing terhadap setiap gram yang terbentuk. Pada proses ini untuk membentuk nilai hash setiap gram, selain parameter ukuran gram, maka diperlukan parameter yang lain berupa nilai basis. Sebagai contoh hash dari 'memban' dengan yang memiliki ukuran gram 6, jika menggunakan nilai basis $=5$, maka dengan rumusan (1) diperoleh nilai hashnya

$$
\begin{aligned}
\operatorname{Hash}_{(\text {memban })}= & \operatorname{ASCII}_{\mathrm{m}} * 5^{(6-1)}+\operatorname{ASCII}_{\mathrm{e}} * 5^{(6-2)} \\
& +\operatorname{ASCII}_{\mathrm{m}} * 5^{(6-3)}+\operatorname{ASCII}_{\mathrm{b}} * 5^{(6-4)} \\
& +\operatorname{ASCII}_{\mathrm{a}} * 5^{(6-5)}+\operatorname{ASCII}_{\mathrm{n}} * 5^{(6-6)} \\
& =420420
\end{aligned}
$$

Pembentukan kode hash tersebut berlaku untuk seluruh gram dengan memakai parameter berupa nilai gram dan basis yang sama. Setelah terbentuk gram kemudian terbentuk nilai hash seluruh gram 
selanjutnya dilakukan proses pembentukan window. Pada pembentukan window diperlukan parameter berupa ukuran window. Sebagai contoh berdasarkan data hasil pembentukan hash dari contoh data sebelumnya, maka jika dibentuk window dengan ukuran window 4, akan dihasilkan window sebagai berikut:

$\begin{array}{lllll}420420.0 & 399091.0 & 417447.0 & \mathbf{3 8 4 2 2 2 . 0}\end{array}$

$\begin{array}{lllll}399091.0 & 417447.0 & \mathbf{3 8 4 2 2 2 . 0} & 389961.0\end{array}$

$\begin{array}{lllll}417447.0 & \mathbf{3 8 4 2 2 2 . 0} & 389961.0 & 434290.0\end{array}$

$\begin{array}{lllll}384222.0 & 389961.0 & 434290.0 & 452803.0\end{array}$

$\begin{array}{lllll}389961.0 & 434290.0 & 452803.0 & 451626.0\end{array}$

$434290.0 \quad 452803.0 \quad 451626.0 \quad \mathbf{4 3 0 1 0 3 . 0}$

$452803.0 \quad 451626.0 \quad 430103.0 \quad \mathbf{4 0 0 6 1 2 . 0}$

$\begin{array}{lllll}451626.0 & 430103.0 & \mathbf{4 0 0 6 1 2 . 0} & 425051.0\end{array}$

$\begin{array}{lllll}430103.0 & \mathbf{4 0 0 6 1 2 . 0} & 425051.0 & 406602.0\end{array}$

$\begin{array}{lllll}\mathbf{4 0 0 6 1 2 . 0} & 425051.0 & 406602.0 & 423745.0\end{array}$

$425051.0 \quad 406602.0 \quad 423745.0 \quad \mathbf{3 8 4 4 4 9 . 0}$

$\begin{array}{lllll}406602.0 & 423745.0 & \mathbf{3 8 4 4 4 9 . 0} & 391096.0\end{array}$

$\begin{array}{lllll}423745.0 & \mathbf{3 8 4 4 4 9 . 0} & 391096.0 & 439964.0\end{array}$

$\begin{array}{lllll}384449.0 & 391096.0 & 439964.0 & 387417.0\end{array}$

$\begin{array}{lllll}391096.0 & 439964.0 & \mathbf{3 8 7 4 1 7 . 0} & 421575.0\end{array}$

$\begin{array}{lllll}439964.0 & \mathbf{3 8 7 4 1 7 . 0} & 421575.0 & 389228.0\end{array}$

$\begin{array}{lllll}387417.0 & 421575.0 & 389228.0 & 399362.0\end{array}$

$\begin{array}{lllll}421575.0 & \mathbf{3 8 9 2 2 8 . 0} & 399362.0 & 418795.0\end{array}$

389228.0 $399362.0 \quad 418795.0 \quad 390953.0$

$\begin{array}{lllll}399362.0 & 418795.0 & \mathbf{3 9 0 9 5 3 . 0} & 439243.0\end{array}$

$\begin{array}{lllll}418795.0 & \mathbf{3 9 0 9 5 3 . 0} & 439243.0 & 399457.0\end{array}$

$\begin{array}{lllll}390953.0 & 439243.0 & 399457.0 & \mathbf{3 8 8 0 0 7 . 0}\end{array}$

$\begin{array}{lllll}439243.0 & 399457.0 & \mathbf{3 8 8 0 0 7 . 0} & 424520.0\end{array}$

$\begin{array}{lllll}399457.0 & \mathbf{3 8 8 0 0 7 . 0} & 424520.0 & 403958.0\end{array}$

$\begin{array}{lllll}388007.0 & 424520.0 & 403958.0 & 410512.0\end{array}$

$\begin{array}{lllll}424520.0 & \mathbf{4 0 3 9 5 8 . 0} & 410512.0 & 443294.0\end{array}$

$\begin{array}{lllll}403958.0 & 410512.0 & 443294.0 & \mathbf{3 8 8 4 4 3 3 . 0}\end{array}$

$\begin{array}{lllll}410512.0 & 443294.0 & \mathbf{3 8 8 4 4 3 . 0} & 426707.0\end{array}$

$\begin{array}{lllll}443294.0 & \mathbf{3 8 8 4 4 3 . 0} & 426707.0 & 414895.0\end{array}$

$\begin{array}{lllll}388443.0 & 426707.0 & 414895.0 & \mathbf{3 8 7 0 7 8 . 0}\end{array}$

$\begin{array}{lllll}426707.0 & 414895.0 & \mathbf{3 8 7 0 7 8 . 0} & 419868.0\end{array}$

$\begin{array}{lllll}414895.0 & \mathbf{3 8 7 0 7 8 . 0} & 419868.0 & 396312.0\end{array}$

387078.0 $\quad 419868.0 \quad 396312.0 \quad 450420.0$

$\begin{array}{lllll}419868.0 & \mathbf{3 9 6 3 1 2 . 0} & 450420.0 & 424078.0\end{array}$

$\begin{array}{lllll}396312.0 & 450420.0 & 424078.0 & 401743.0\end{array}$

$\begin{array}{lllll}450420.0 & 424078.0 & 401743.0 & \mathbf{3 9 9 4 5 7 . 0}\end{array}$

$\begin{array}{lllll}424078.0 & 401743.0 & 399457.0 & \mathbf{3 8 8 0 0 7 . 0}\end{array}$

$\begin{array}{lllll}401743.0 & 399457.0 & \mathbf{3 8 8 0 0 7 . 0} & 424520.0\end{array}$

$\begin{array}{lllll}399457.0 & \mathbf{3 8 8 0 0 7 . 0} & 424520.0 & 403958.0\end{array}$

$\begin{array}{lllll}\mathbf{3 8 8 0 0 7 . 0} & 424520.0 & 403958.0 & 410520.0\end{array}$

$\begin{array}{lllll}424520.0 & \mathbf{4 0 3 9 5 8 . 0} & 410520.0 & 443334.0\end{array}$

$\begin{array}{lllll}403958.0 & 410520.0 & 443334.0 & \mathbf{3 8 8 6 5 7 . 0}\end{array}$

$\begin{array}{lllll}410520.0 & 443334.0 & \mathbf{3 8 8 6 5 7 . 0} & 427757.0\end{array}$

Nilai-nilai di atas merupakan window yang tersusun oleh nilai-nilai hash dari setiap gram. Adapun nilai hash yang tercetak tebal merupakan nilai-nilai terkecil tiap baris pada window yang akan menjadi kandidat pembentuk fingerprint pada proses selanjutnya yakni fingerprinting. Fingerprint diperoleh dengan cara memilih nilai hash terkecil dari setiap window yang ada. Khusus jika ada beberapa window yang berurutan memiliki nilai hash terkecil yang sama, maka dipilih satu nilai hash saja yakni yang berada diposisi paling kanan. Berdasarkan data window yang dihasilkan dari proses terhadap teks pada contoh sebelumny, maka, maka fingerprint untuk data teks trsebut adalah :

$384222.0 \quad 389961.0 \quad 430103.0 \quad 400612.0$

$\begin{array}{llll}384449.0 & 387417.0 & 389228.0 & 390953.0\end{array}$

$\begin{array}{lllll}388007.0 & 403958.0 & 388443.0 & 387078.0\end{array}$

$396312.0 \quad 399457.0 \quad 388007.0 \quad 403958.0$ 388657.0

Fingerprint tersebut nantinya yang akan mewakili dokumen teks, yang akan dibandingkan dengan fingerprint teks lain untuk proses penghitungan nilai kemiripan. Pada sistem yang dibangun ini pembentukan fingerprint juga diterapkan untuk teks gejala sakit yang dimasukkan ke dalam sistem oleh user.

Sebagai contoh teks gejala sakit 'sering mual lambung terasa kembung kadang cemas'. setelah dilakukan proses yang sama sebagaimana terhadap teks manfaat tanaman obat, maka dengan parameter fingerprint yang sama yakni basis $=5$, gram $=6$, window $=4$, akan diperoleh nilai fingerprint $\begin{array}{llll}385957.0 & 407698.0 & 403374.0 & 387839.0\end{array}$ $\begin{array}{llll}396332.0 & 387078.0 & 402467.0 & 403970.0\end{array}$ $\begin{array}{llll}410450.0 & 396381.0 & 390414.0 & 381114.0\end{array}$ 387193.0

Tahapan pada sistem berikutnya adalah penghitungan nilai kemiripan antara dua dokumen teks. Setelah dokumen-dokumen teks memiliki fingerprint dari proses fingerprinting dengan ukuran gram yang sama, basis yang sama, dan ukuran window yang sama, maka langkah selanjutnya adalah menghitung prosentase kemiripan kedua dokumen teks tersebut dengan rumus Jaccard's Similarity Coefficient.

Berdasarkan contoh dari kedua teks tersebut yakni teks manfaaat tanaman obat berupa 'membantu pengobatan cemas, ganguan lambung, gangguan limpa' dan teks gejala sakit berupa 'sering mual lambung terasa kembung kadang cemas' terlihat memiliki nilai fingerprint yang sama sebanyak 1 buah yakni 3807078.0. Sedangkan jumlah fingerprint kedua teks tersebut sebanyak 27 buah, sehingga berdasarkan rumusan diperoleh nilai kemiripan fingerprint keduanya adalah:

Kemiripan $_{(\text {gejala,manfaat })=}$

$$
\begin{aligned}
& =\frac{\mid \text { gejala } \cap \text { manfaat } \mid}{\mid \text { gejala } \cup \text { manfaat } \mid} \times 100 \\
& =\frac{1}{27} \times 100 \\
& =3,7 \%
\end{aligned}
$$

\section{Hasil dan Pembahasan \\ Penentuan Parameter Fingerprint}

Pada implementasi sistem yang dibangun, setelah proses rekam data tanaman obat, dan 
pembentukan fingerprint seluruh data teks manfaat tanaman obat, maka diperlukan proses pengujian untuk penentuan parameter fingerprint. Pengujian ini bertujuan untuk menemukan nilai-nilai terbaik dari ketiga parameter pembentuk fingerprint pada sistem ini. Parameter tersebut adalah ukuran gram, basis, dan ukuran window.

Langkah penentuan parameter fingerprint diawali dengan mengambil sebagian data dari tabel fingerprint, yang ada di basis data, untuk menjadi menjadi data training. Pada pengujian ini mencoba menggunakan bilangan basis berupa bilangan ganjil baik bilangan prima maupun tidak, dan akan diamati pengaruhnya terhadap terjadinya collision. Collision adalah tumbukan nilai hash atau secara sederhana sebuah nilai hash ternyata dipakai untuk lebih dari satu gram yang berbeda. Secara logika keberadaan collison dari nilai hash akan menjadikan hasil kemiripan fingerprint tidak akan menunjukkan gambaran nilai kemiripan yang sebenarnya.

Pada pengujian ini dinputkan beberapa kali nilai-nilai parameter fingerprint ke antarmuka sistem yang dibangun. Pengujian melibatkan data teks tanaman obat sebanyak 340 buah, dimana akan saling dibandingkan tingkat kemiripan diantara data fingerprint teks manfaat tanaman tersebut. Adapun ukuran gram yang digunakan dipilih cenderung nilainilai yang kecil karena menyesuaikan jumlah karakter penyusun teks manfaat tanaman obat dari file teks tanaman obat yang rata-rata jumlah karakternya tidak begitu banyak. Sedangkan nilai window maksimal yang dimasukkan adalah dengan pendekatan perkiraan jumlah gram yang akan dibentuk dari rangkaian karakter teks manfaat tanaman obat. Ukuran window yang melewati jumlah gram akan berdampak tidak terbentuknya window, dan hal ini tentu saja berakibat tidak bisa terbentuk fingerprint karena tidak ada nilai hash yang dari window, dan otomatis tidak menghasilkan nilai kemiripan.

Pengujian dilakukan dengan berbagai kombinasi paramater yang dicobakan, diantaranya menggunakan input nilai basis 11 dan gram 4 sampai 15 serta ukuran window 1 sampai 7. Selanjutanya kembali dicoba dilakukan uji parameter fingerprint yang lain, yakni dengan nilai basis dirubah menjadi 19, 21 dan 23. Hasil pengujian menunjukkan bahwa basis 11 dengan gram 4 sampai 15, dan window 1 sampai 7 menghasilkan collision-collision, hal ini ditunjukkan dengan hasil dari penelusuran collison dengan menggunakan perintah query terhadap data hash pembentuk fingerprint di basis data.

Pengujian dilanjutkan dengan basis 19, 21 dan 23. Hasil pengujian menunjukkan pada basis 19 dan 23 masih menghasilkan collision-collision. Sedangkan untuk basis 21 pada gram 5 sampai 13 dan ukuran window 1 tidak menghasilkan collision, namun bila dengan gram 12 dan 13 akan terbentuk collision, sehingga nilai basis 21 ini menjadi pilihan.
Tahapan selanjutnya adalah memilih sebuah kombinasi parameter fingerprint dengan basis 21 . Tahapan ini dilakukan dengan proses sebagaimana sebelumnya namun dengan gram 5 sampai 10, dan window antara 1 sampai 5. Pilihan gram 5 sampai 10, dikarenakan kombinasi basis 21 dengan gram-gram tersebut tidak menunjukkan adanya collision untuk window 1. Pengujian ini dengan menggunakan sebanyak 30 data teks tanaman obat.

Ketika nilai window sama dengan 1 tidak menunjukkan collision maka harapannya nilai window yang lebih besar secara logika sudah tidak ada collision. Gambaran tersebut bisa dilihat sebagaimana gambar grafik berikut ini.

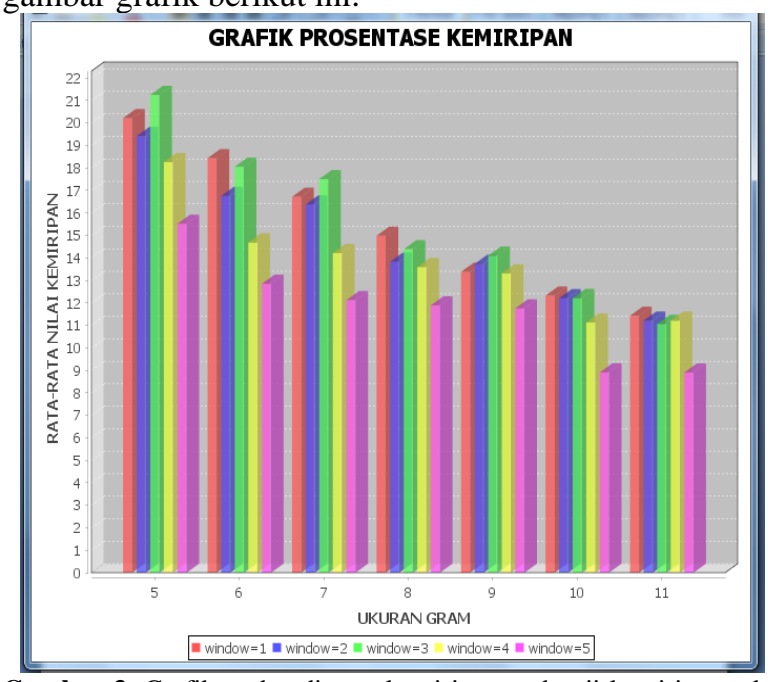

Gambar 3. Grafik perbandingan kemiripan pada uji kemiripan teks manfaat tanaman obat dengan basis $=21$ dengan beberapa ukuran gram dan variasi window

Pada gambar 3 tersebut terlihat, ketika nilai gram semakin besar maka semakin menurun nilai kemiripan. Hal ini dimungkinkan karena semakin besar ukuran gram maka cenderung semakin sedikit terbentuknya jumlah gram. Jika sampai jumlah gram sampai kurang dari ukuran window akan menjadikan window tidak terbentuk. Ketika window tidak terbentuk maka fingerprint juga tidak dibentuk. sehingga perhitungan nilai kemiripan tidak ada.

Gambar grafik berikut ini menunjukkan gambaran ukuran window yang lebih kecil cenderung memiliki nilai kemiripan yang lebih tinggi. 


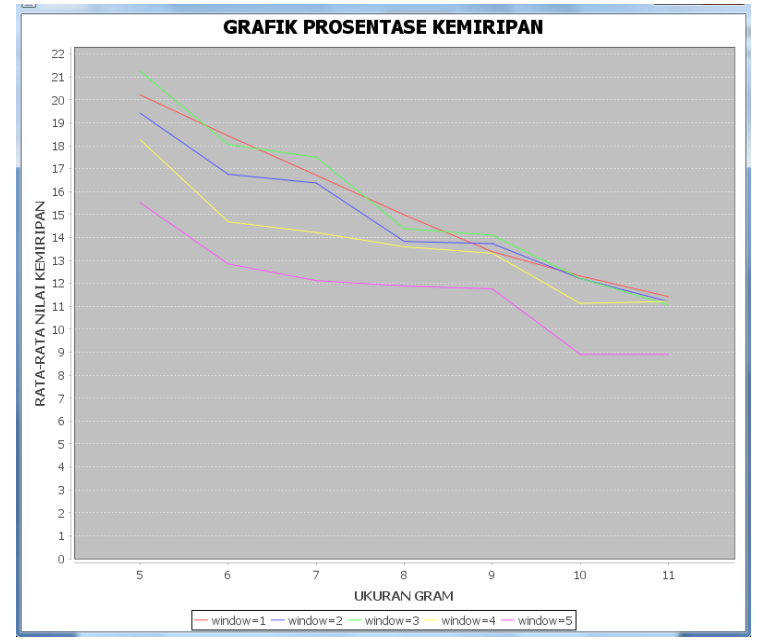

Gambar 4. Grafik pola perbandingan kemiripan pada uji kemiripan teks manfaat tanaman obat dengan basis $=21$ dengan beberapa ukuran gram dan variasi window

Ilustrasi sebagimana pada gambar 4 tersebut dimungkinan terjadi karena ukuran window yang lebih kecil, memungkinkan lebih banyak fingerprint yang dihasilkan yang demikian tentu akan memperbanyak kemungkinan nilai kemiripan

\section{Pengujian Kinerja Sistem}

Pengujian kinerja sistem dilakukan dengan dengan memasukkan teks query gejala-gejala sakit ke dalam sistem. Adapun teks gejala-gejala sakit seperti terdapat dalam tabel berikut ini.

Tabel 2. Teks query gejala-gejala sakit

\begin{tabular}{cl}
\hline NOMOR & \multicolumn{1}{c}{ GEJALA SAKIT } \\
\hline 1 & gejala kencing manis \\
\hline 2 & luka baru terkena benda tajam \\
\hline 3 & perut mulas, diare atau mencret \\
\hline 4 & $\begin{array}{l}\text { sakit kepala, pusing atau pening dan } \\
\text { tekanan darah tinggi }\end{array}$ \\
\hline 5 & perdarahan pada luka \\
\hline 6 & sakit gigi \\
\hline 7 & susah buang air besar, atau sembelit \\
\hline 14 & $\begin{array}{l}\text { lambung nyeri, perut mual, kembung, } \\
\text { maag }\end{array}$ \\
\hline 10 & $\begin{array}{l}\text { nafsu makan berkurang } \\
\text { berdarah }\end{array}$ \\
\hline 11 & $\begin{array}{l}\text { kulit melepuh terkena luka bakar } \\
\text { dan pilek }\end{array}$ \\
\hline 12 & $\begin{array}{l}\text { radang saluran kencing, kencing } \\
\text { bernanah, buang air seni tidak lancar }\end{array}$ \\
\hline 15 & gondok pada leher \\
\hline 14 & bangang pegal, linu, encok \\
\hline 10 &
\end{tabular}

Proses selanjutnya teks query tersebut oleh sistem akan dibentuk fingerprintnya, dengan parameter yang telah diuji sebagaimana telah dijelaskan sebelumnya.

Pengujian kinerja sistem ini menggunakan nilai-nilai parameter pembentuk fingerprint yang dianggap baik, sebanyak 4 kombinasi dari nilai basis, gram dan window. Perlakuan yang sama diterapkam terhadap teks manfaat tanaman obat yang ada di dalam basis data yakni sebanyak 340 data teks tanaman obat. Selanjutnya dilakukan proses penghitungan tingkat kemiripan keduanya.

Hasil dari tampilan proses perhitungan kemiripan teks manfaat tanaman obat akan diperiksa relevan atau tidak dengan teks gejala sakit.Teks query dinyatakan ditemukan jika nilai kemiripan terhadap teks manfaat tanaman obat lebih besar dari nol, dan dinyatakan tidak ditemukan jika nilai kemiripan terhadap teks manfaat tanaman obat adalah nol. Teks yang ditemukan dinyatakan relevan jika mengandung rangkaian kata yang memiliki makna yang sama.

Untuk mengetahui yang dihasilkan sistem relevan atau tidak, maka perlu dilakukan pengecekan secara manual. Kinerja sistem ini dinyatakan dengan nilai rata-rata recall dan precision, dengan berdasarkan konsep yang telah dijelaskan pada rumusan (3) dan rumusan (4) sebelumnya.

Tabel-tabel berikut ini menunjukkan hasil pengujian kinerja sistem dari setiap penggunaan parameter fingerprint, yang diujikan.

Tabel 3. basis 21 gram 5 dan window 3

\begin{tabular}{|c|c|c|c|c|c|}
\hline $\begin{array}{l}\text { Gejala } \\
\text { Ke- }\end{array}$ & tp & fp & $t p+f n$ & Recall & Precision \\
\hline 1 & 7 & 10 & 7 & 1,00 & 0,41 \\
\hline 2 & 10 & 0 & 10 & 1,00 & 1,00 \\
\hline 3 & 40 & 3 & 49 & 0,82 & 0,93 \\
\hline 4 & 34 & 43 & 35 & 0,97 & 0,44 \\
\hline 5 & 7 & 6 & 7 & 1,00 & 0,54 \\
\hline 6 & 6 & 0 & 6 & 1,00 & 1,00 \\
\hline 7 & 27 & 0 & 27 & 1,00 & 1,00 \\
\hline 8 & 16 & 11 & 21 & 0,76 & 0,59 \\
\hline 9 & 25 & 5 & 25 & 1,00 & 0,83 \\
\hline 10 & 17 & 36 & 17 & 1,00 & 0,32 \\
\hline 11 & 2 & 11 & 2 & 1,00 & 0,15 \\
\hline 12 & 50 & 32 & 70 & 0,71 & 0,61 \\
\hline 13 & 2 & 0 & 2 & 1,00 & 1,00 \\
\hline 14 & 66 & 18 & 83 & 0,80 & 0,79 \\
\hline 15 & 8 & 7 & 8 & 1,00 & 0,53 \\
\hline \multicolumn{4}{|c|}{ Rata-rata } & 0,94 & 0,68 \\
\hline
\end{tabular}

Hasil pengujian kinerja sistem sebagaimana pada table 5, menunjukkan pemakaian parameter fingerprint berupa nilai basis $=21$ gram $=5$ dan window $=3$ menghasilkan nilai rata-rata recall sebesar $94 \%$ dan precision sebesar $68 \%$. 
Muryanto dan Setyawan, Penentuan Kemiripan Manfaat Tananaman Obat dengan Gejala Sakit Menggunakan Algoritma Winnowing

Tabel 4. basis 21 gram 7 dan window 1

\begin{tabular}{rrrrrr}
\hline $\begin{array}{l}\text { Gejala } \\
\text { Ke- }\end{array}$ & tp & fp & tp+fn & Recall & \multicolumn{1}{l}{ Precision } \\
\hline $\mathbf{1}$ & 7 & 10 & 7 & 1,00 & 0,41 \\
\hline $\mathbf{2}$ & 10 & 0 & 10 & 1,00 & 1,00 \\
\hline $\mathbf{3}$ & 41 & 0 & 49 & 0,84 & 1,00 \\
\hline $\mathbf{4}$ & 28 & 12 & 35 & 0,80 & 0,70 \\
\hline $\mathbf{5}$ & 7 & 3 & 7 & 1,00 & 0,70 \\
\hline $\mathbf{6}$ & 6 & 0 & 6 & 1,00 & 1,00 \\
\hline $\mathbf{7}$ & 27 & 0 & 27 & 1,00 & 1,00 \\
\hline $\mathbf{8}$ & 17 & 5 & 21 & 0,81 & 0,77 \\
\hline $\mathbf{9}$ & 25 & 0 & 25 & 1,00 & 1,00 \\
\hline $\mathbf{1 0}$ & 16 & 6 & 17 & 0,94 & 0,73 \\
\hline $\mathbf{1 1}$ & 2 & 4 & 2 & 1,00 & 0,33 \\
\hline $\mathbf{1 2}$ & 70 & 12 & 70 & 1,00 & 0,85 \\
\hline $\mathbf{1 3}$ & 0 & 0 & 2 & 0,00 & - \\
\hline $\mathbf{1 4}$ & 11 & 3 & 83 & 0,13 & 0,79 \\
\hline $\mathbf{1 5}$ & 5 & 0 & 8 & 0,63 & 1,00 \\
\hline \multicolumn{7}{c}{ Rata-rata } & 0.81 & 0,81 \\
\hline
\end{tabular}

Pada pengujian kinerja sistem sebagaimana digambarkan pada tabel 4 , menunjukkan pemakaian parameter fingerprint berupa nilai basis $=21$ gram $=7$ dan window $=1$ menghasilkan nilai rata-rata recall sebesar $81 \%$ dan precision sebesar $81 \%$.

Tabel 5. basis 21 gram 7 dan window 3

\begin{tabular}{rrrrrr}
\hline $\begin{array}{l}\text { Gejala } \\
\text { Ke- }\end{array}$ & tp & $\mathbf{f p}$ & tp+fn & Recall & \multicolumn{1}{l}{ Precision } \\
\hline $\mathbf{1}$ & 7 & 0 & 7 & 1,00 & 1,00 \\
\hline $\mathbf{2}$ & 0 & 0 & 10 & 0,00 & - \\
\hline $\mathbf{3}$ & 2 & 0 & 49 & 0,04 & 1,00 \\
\hline $\mathbf{4}$ & 28 & 12 & 35 & 0,80 & 0,70 \\
\hline $\mathbf{5}$ & 7 & 1 & 7 & 1,00 & 0,88 \\
\hline $\mathbf{6}$ & 6 & 0 & 6 & 1,00 & 1,00 \\
\hline $\mathbf{7}$ & 27 & 0 & 27 & 1,00 & 1,00 \\
\hline $\mathbf{8}$ & 3 & 0 & 21 & 0,14 & 1,00 \\
\hline $\mathbf{9}$ & 25 & 0 & 25 & 1,00 & 1,00 \\
\hline $\mathbf{1 0}$ & 16 & 1 & 17 & 0,94 & 0,94 \\
\hline $\mathbf{1 1}$ & 2 & 4 & 2 & 1,00 & 0,33 \\
\hline $\mathbf{1 2}$ & 57 & 5 & 70 & 0,81 & 0,92 \\
\hline $\mathbf{1 3}$ & 0 & 0 & 2 & 0,00 & - \\
\hline $\mathbf{1 4}$ & 10 & 0 & 83 & 0,12 & 1,00 \\
\hline $\mathbf{1 5}$ & 5 & 0 & 8 & 0,63 & 1,00 \\
\hline \multicolumn{7}{c}{ Rata-rata } & 0,63 & 0,91 \\
\hline
\end{tabular}

Pengujian kinerja sistem sebagaimana terlihat pada tabel 5, menunjukkan dengan menggunakan parameter fingerprint berupa nilai basis $=21$ gram $=7$ dan window $=3$ menghasilkan nilai rata-rata recall sebesar $63 \%$ dan precision sebesar $91 \%$.
Tabel 6. basis 21 gram 8 dan window 1

\begin{tabular}{rrrrrr}
\hline $\begin{array}{l}\text { Gejala } \\
\text { Ke- }\end{array}$ & tp & $\mathbf{f p}$ & $\mathbf{t p}+\mathbf{f n}$ & Recall & Precision \\
\hline $\mathbf{1}$ & 7 & 0 & 7 & 1,00 & 1,00 \\
\hline $\mathbf{2}$ & 10 & 0 & 10 & 1,00 & 1,00 \\
\hline $\mathbf{3}$ & 3 & 0 & 49 & 0,06 & 1,00 \\
\hline $\mathbf{4}$ & 28 & 0 & 35 & 0,80 & 1,00 \\
\hline $\mathbf{5}$ & 7 & 1 & 7 & 1,00 & 0,88 \\
\hline $\mathbf{6}$ & 6 & 0 & 6 & 1,00 & 1,00 \\
\hline $\mathbf{7}$ & 27 & 0 & 27 & 1,00 & 1,00 \\
\hline $\mathbf{8}$ & 4 & 0 & 21 & 0,19 & 1,00 \\
\hline $\mathbf{9}$ & 25 & 0 & 25 & 1,00 & 1,00 \\
\hline $\mathbf{1 0}$ & 17 & 0 & 17 & 1,00 & 1,00 \\
\hline $\mathbf{1 1}$ & 2 & 8 & 2 & 1,00 & 0,20 \\
\hline $\mathbf{1 2}$ & 13 & 5 & 70 & 0,19 & 0,72 \\
\hline $\mathbf{1 3}$ & 0 & 0 & 2 & 0,00 & - \\
\hline $\mathbf{1 4}$ & 7 & 0 & 83 & 0,08 & 1,00 \\
\hline $\mathbf{1 5}$ & 5 & 0 & 8 & 0,63 & 1,00 \\
\hline & & Rata-rata & 0,66 & 0,91 \\
\hline & & & & & \\
\hline
\end{tabular}

Pada tabel 6, menunjukkan hasil pengujian kinerja sistem dengan menggunakan parameter fingerprint berupa nilai basis $=21$ gram $=8$ dan window $=1$ menghasilkan nilai rata-rata recall sebesar $66 \%$ dan precision sebesar $91 \%$.

Berdasarkan hasil pengujian-pengujian tersebut maka nilai parameter pembentuk fingerprint yang dipilih adalah basis $=21$, gram $=7$ dan window $=1$, dimana menghasilkan nilia rata-rata recall sebesar $81 \%$ dan rata-rata precision sebesar $81 \%$. Parameter ini akan menjadi dasar pembentukan fingerprint baik teks manfaat tanaman obat yang akan tersimpan dalam basis data, maupun teks gejala sakit yang diinputkan oleh user, yang dimana keduanya akan akan dihitung tingkat kemiripannya untuk menjadi dasar pemilihan tanaman obat yang paling pas berdasar gejala sakit.

Pada setiap hasil nilai kemiripan, maka user bisa melihat tampilan informasi detail data tanaman obat seperti gambar 5. berikut ini. 


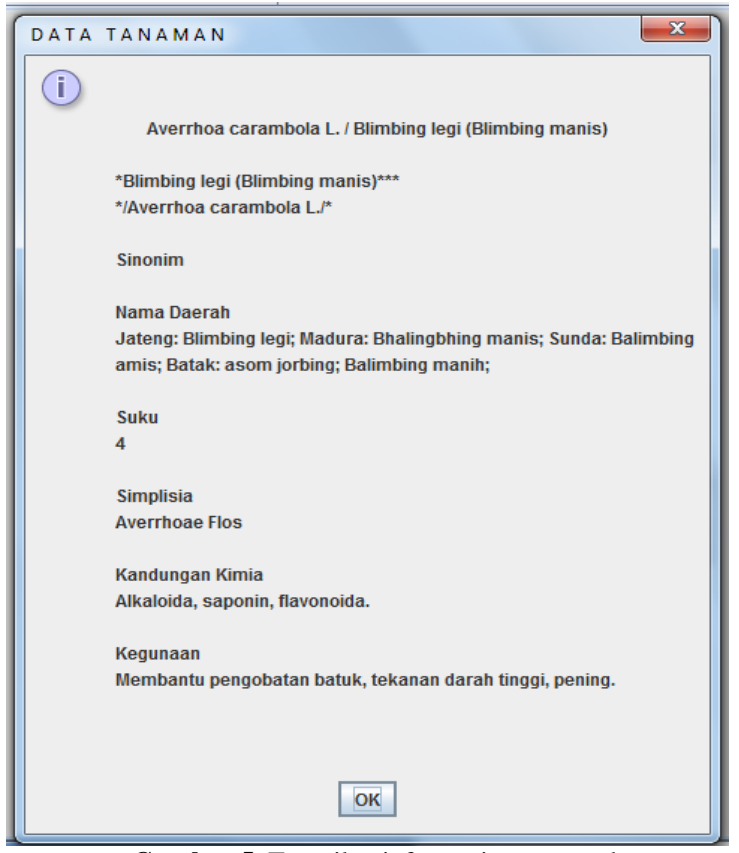

Gambar 5. Tampilan informasi tanaman obat

Tampilan detail informasi tanaman obat yang dimunculkan oleh system tersebut, akan mirip dengan tampilan halaman web site sumber untuk tiap tanaman obat.

\section{Pembahasan}

Teks query gejala sakit yang dimasukkan ke sistem, bisa saja dinyatakan ditemukan namun tidak relevan. Hal ini bisa terjadi misal dikarenakan adanya potongan kata dari gram yang ikut terdeteksi sebagai fingerprint yang sama, padahal sebenarnya rangkaian gram tersebut bukan bagian kata yang tekait dengan relevansi makna dari teks query.

Misal teks query 'gejala tekanan darah tinggi'. Secara umum jika pada teks-teks manfaat tanaman obat mengandung rangkaian kata tersebut maka akan dinyatakan ditemukan. Namun bisa saja diantara yang dinyatakan ditemukan ternyata tidak relevan, misal dalam teks manfaat tanaman obat terkandung kalimat 'mengobati gejala tekanan darah rendah'. Teks ini jelas tidak relevan dengan teks query. Kalau diteliti ternyata terdapat gram yang sama dengan gram yang dihasilkan teks ini. Teks ini mengandung beberapa gram yang sama dengan teks query' gejala tekanan darah tinggi', namun sebenarnya tidak relevan. Hal demikian bisa diberi solusi dengan cara menaikkan ukuran gram menjadi semakin besar nilainya, akan tetapi hal ini harus mempertimbngkan jumlah karakter penyusun teks gejala dan teks tanaman obat. Pada penelitian ini teks manfaat tanaman obat jumlah rata-rata kata-kata yang menyusunnya relatif sedikit, sehingga ketika ukuran gram nilainya dinaikkan maka jumlah gram yang dihasilkan menjadi berkurang, dan semakin sedikit dan bahkan sampai tidak menghasilkan gram sama sekali. Kenaikan ukuran gram juga tidak mesti menjamin bahwa data yang ditemukan bebas dari data yang tidak relevan. Kalau ukuran gram ditingkatkan terus maka dari teks yang tidak relevan yang dinyatakan ditemukan mungkin akan berkurang, namun bisa berdampak juga teks yang sebenarnya releven dengan query malah banyak dinyatakan tidak ditemukan. Hal inilah yang menjadi alasan perlunya diadakan pengujian sejauh mana kemampuan sistem dengan kombinasi parameter fingerprintnya dalam mendeteksi teks yang ditemukan dinyatakan adalah relevan.

Dari hasil pengujian terlihat bahwa parameter fingerprint dengan nilai basis $=21$, gram $=7$ dan window $=1$ menghasilkan kinerja sistem yang lebih baik dari kombinasi parameter fingerprint lainya yang diujikan. Hal ini terlihat dari nilai rata-rata precision yakni $81 \%$. Dalam menemukan informasi yang ada dalam koleksi di basis data, yang relevan dengan query yang dimasukkan dalam sistem, maka, sistem ini juga menunjukkan kinerja yang cukup baik yakni ditunjukkan dengan nilai rata-rata recall sebesar $81 \%$. Selanjutnya parameter fingerprint tersebut akan menjadi parameter yang direkomendasikan untuk dipakai user ketika menggunakan sistem ini dalam mencari data tanaman obat berdasar kemiripan antara manfaat tanaman obat dengan gejala sakit.

\section{Kesimpulan}

Beberapa kesimpulan yang dapat ditarik dari hasil penelitian ini yaitu pertama, ukuran gram yang kecil secara umum akan lebih menaikkan nilai hasil deteksi kemiripan.

Keberadaan kata yang berdekatan dengan sebuah kata yang menjadi bagian dari gram yang ingin dicari dalam kalimat, akan mempengaruhi terdeteksi atau tidaknya gram yang mengandung kata tersebut.

Ukuran window akan sangat ditentukan ukuran gram. Sebuah window akan terbentuk minimal oleh keberadaan jumlah gram yang terbentuk, jika jumlah gram kurang dari ukuran window yang diinginkan maka window tidak akan terbentuk.

Keberadaan window akan menentukan keberadaan fingerprint, sehingga jika window tidak terbentuk maka fingerprint pun juga tidak ada. Jika fingerprint tidak ada maka nilai kemiripan menjadi tidak ada. Sehingga jika deretan kata yang akan dibentuk fingerprint memiliki jumlah kata yang sedikit, seperti pada sistem ini, maka ukuran window sebaiknya juga kecil

Sistem ini secara umum memilki kinerja yang cukup baik untuk penentuan kemiripan antara teks gejala sakit dan teks manfaat tanaman obat Hal ini ditunjukkan dengan nilai rata-rata precision sebesar $81 \%$, dan rata-rata recall sebesar $81 \%$, yang dihasilkan dari kombinasi parameter fingerprint berupa nilai basis $=21$, gram $=7$ dan window $=1$. 


\section{REFERENSI}

[1] H. dan T. Marwati, Teknologi Pasca Panen Tanaman Obat. Bogor: BB Pasca Panen Bogor, 2012.

[2] Katno, Pengelolaan Pasca Panen Tanaman Obat. Tawangmangu: Balai Besar Penelitian dan Pengembangan Tanaman Obat dan Obat Tradisional Badan Penelitian dan Pengembangan Kesehatan Departemen Kesehatan RI, 2008.

[3] D. Purwitasari, "Deteksi Keberadaan Kalimat Sama Sebagai Indikasi Penjiplakan Dengan Algoritma Hashing Berbasis N-Gram," J. Ilm. KURSOR, vol. 6, no. 1, 2017.

[4] S. Salmuasih and A. Sunyoto, "Implementasi Algoritma Rabin Karp Untuk Pendeteksian Plagiat Dokumen Teks Menggunakan Konsep Similarity," J. Inov. dan Kewirausahaan, p. 124956, 2013.

[5] A. Kurniawati and I. Wicaksana, "Perbandingan Pendekatan Deteksi Plagiarism Dokumen Dalam Bahasa Inggris," Proceeding, Semin. Ilm. Nas. Komput. dan Sist. Intelijen (KOMMIT 2008), 2008.

[6] A. Aljohani and M. Mohd, "Arabic-English Cross Language Plagiarism Detection Using Winnowing Algorithm," Inf. Technol. J., vol. 13, no. 14, p. 2349, 2014.

[7] S. Stein, B. dan Meyer Zu, "Fingerprint Based Similarity Search And Plagiarism Analysis," 29th Annu. Conf. Ger. Classif. Soc. Appl. Magdeburg, ISDN 1431-8814,pp.430-437, 2006.

[8] U. Manber, "Finding Similar Files In A Large File System.," in Usenix winter, 1994, vol. 94, pp. $1-10$.

[9] D. Zou, W.-J. Long, and Z. Ling, "A ClusterBased Plagiarism Detection Method-Lab Report For PAN At CLEF 2010.," 2010.

[10] S. Schleimer, D. S. Wilkerson, and A. Aiken, "Winnowing: Local Algorithms For Document Fingerprinting," in Proceedings of the 2003 ACM SIGMOD international conference on Management of data, 2003, pp. 76-85.

[11] R. M. Karp and M. O. Rabin, "Efficient Randomized Pattern Matching Algorithms," IBM J. Res. Dev., vol. 31, no. 2, pp. 249-260, 1987.

[12] P. Jaccard, "The Distribution Of The Flora In The Alpine Zone. 1," New Phytol., vol. 11, no. 2, pp. 37-50, 1912.

[13] G. Lu, Multimedia Database Management Systems. Boston, MA: Artech House, 1999.

[14] H. Schütze, C. D. Manning, and P. Raghavan, Introduction To Information Retrieval, vol. 39. Cambridge University Press Cambridge, 2008. 